\title{
Marital physical violence suffered and committed by men: repeating family patterns?
}

\author{
Aline Riboli Marasca - Universidade do Vale do Rio dos Sinos, São Leopoldo, Brasil \\ Josiane Razera - Universidade do Vale do Rio dos Sinos, São Leopoldo, Brasil \\ Henrique Juliano Rosa Pereira - Universidade do Vale do Rio dos Sinos, São Leopoldo, Brasil \\ Denise Falcke - Universidade do Vale do Rio dos Sinos, São Leopoldo, Brasil
}

\begin{abstract}
Intending to contribute to the marital violence theme, this article has the objective to investigate the presence of physical violence suffered and committed by men in family relationships and the predictive power of family of origin experiences on this occurrence in a sample of 186 men. A sociodemographic questionnaire, Family Background Questionnaire (FBQ) and Revised Conflict Tactics Scale (CTS2) were used to collect the data. Physical violence suffered and committed by men established significant correlations with experiences of violence in the family of origin. The predictive factor for the occurrence was the experience of parental physical abuse in childhood. We discuss the relevance of a focus of attention on men also as victims of marital violence and the relevance of understanding the role of family of origin for the maintenance of violence in future relations.

Keywords: family violence, family relations, men.
\end{abstract}

Violência física conjugal sofrida e cometida por homens: repetindo padrões familiares?

\begin{abstract}
Resumo
Com vistas de contribuir para a temática da violência conjugal, o presente estudo teve como objetivo investigar a presença de violência física sofrida e cometida por homens nos relacionamentos íntimos e o poder preditivo das experiências na família de origem nessa ocorrência, em uma amostra de 186 homens. Um questionário de informações sociodemográficas, o Family Background Questionnaire (FBQ) e a Revised Conflict Tactics Scales (CTS2) foram utilizados para coletar os dados. A violência física cometida e sofrida pelos homens obteve correlações significativas com as experiências de violência na família de origem. Verificou-se que o fator preditor para a ocorrência foi a vivência de abuso físico paterno na infância. Discute-se a relevância de um foco de atenção dos estudos nos homens como também vítimas de violência conjugal e a relevância de compreender o papel das famílias de origem para a perpetuação da violência em relacionamentos adultos.

Palavras-chave: violência na família, relações familiares, homens.
\end{abstract}

Violencia Física Conyugal sufrida y cometida por hombres: Repitiendo los patrones familiares?

\begin{abstract}
Resumen
Con el fin de contribuir a la temática de la violencia conyugal, este estudio tuvo como objetivo investigar la presencia de violencia física sufrida y cometida por hombres en sus relaciones íntimas y el poder predictivo de las experiencias en la familia de origen, en esta ocasión, en una muestra de 186 hombres. Un cuestionario de informaciones sociodemográficas, el Family Background Questionnaire (FBQ) y la Revised Conflict Tactics Scale (CTS2) se utilizaron para recopilar los datos. La violencia física cometida y sufrida por los hombres obtuvo correlaciones significativas con las experiencias de violencia en la familia de origen. Se comprobó que el factor predictor para la ocasión fue la experiencia de abuso físico paterno en la infancia. Es importante prestar atención en los estudios de los hombres, como víctimas también de violencia conyugal, y la importancia de comprender el papel de las familias de origen para la perpetuación de la violencia en las relaciones adultas.

Palabras-clave: violencia doméstica, relaciones familiares, hombres.
\end{abstract}

The issue of domestic violence, marked by a culture of silence, has had the attention of society in the context of public policies and scientific circles, because of its serious consequences. The phenomenon of visibility arrived with feminist movements, which acted demanding better living conditions and equal rights for women (Ribeiro, 2010). The concept of gender began to be used as a category of violence analysis in marital life, knowing that there is a historical and social construction of masculine and feminine, which converts into an inequality in favor of men (Santos \& Izumino, 2005).
Since then, most scientific studies on the theme apply the notion of gender as a way of understanding violence between partners, identifying the roles of male perpetrator and female victim, the existence of traditional conceptions of social roles, and the need to reproduce the traditional family structure (Cortez \& Souza, 2008; Jong, Sadala, \& Tanaka, 2008; Pazo \& Aguiar, 2012). However, such studies, despite intending to fight for gender equality, by considering women as victims and understanding their acts of violence only as reactive to violence inflicted by their partner (Alvim 
\& Souza, 2005) via subjugation or resistance (Narvaz \& Koller, 2006), may end up by reinforcing the woman's place of victimization and the impossibility of her active role in the context of marital relationships.

Some questions have arisen regarding the interpretation of cases of domestic violence and the prevailing view that it occurs only against women. In this sense, it is clear that there are two ways of understanding this phenomenon in current literature. The first perspective reflects the views of feminist scholars who regard sexism as the main cause of violence against women, acknowledging the idea of a patriarchal social structure, delegating the role of perpetrator to men. The second perspective describes sexism as one of the facets of violence between couples, showing that partners tend to have a more symmetrical relationship and that violence is an interactional phenomenon (Alvim \& Souza, 2005; Harris, Palazzolo, \& Savage, 2012; Otálvaro \& Amar, 2011; Próspero, 2007; Straus, 1990).

This second view is advocated by Straus (2008, 2010, 2011), who sees gender symmetry in domestic violence, a notion that has implications on the field of prevention and treatment. Reviewing previous studies, Straus (2010) understands that the methodology used is biased towards violence against women and presents results that indicate women as perpetrators of violence in the marital relationship, especially when the investigation includes couples of the population in general and not only cases of violence that were reported. In this sense, it is possible to identify that the studies which state the prevalence of violence against men or women vary a lot in terms of sources and measuring instruments, and are often non-validated tools to estimate the prevalence of men victims of violence (Machado \& Matos, 2014; Mills, Avegno, \& Haydel, 2006).

Based on similar discussions, research groups around the world seek to increase knowledge around domestic violence, including data on female perpetration and the resulting male victimization. In Portugal, a study by Carmo, Grams and Magalhães (2011) pointed out that, among the cases of domestic violence analyzed in a forensic medical department, $11.5 \%$ were of men physically assaulted by the female partner. However, such as showed by other studies, a greater number is estimated, due to the underreporting of such violence. In the Netherlands, Drijver, Reijnders and Ceelen (2013) investigated the characteristics of male victims of domestic violence and found that in 90\% of cases, the aggressor was a current or former partner, and 67\% suffered physical and emotional abuse.
The main reasons for not reporting the incidents to the police were: fear of not being taken seriously, shame, belief that the police could not do anything, fear that violence could worsen, and fear of revenge. It was also identified that men refused the aid when the situation was reported, reinforcing stereotypes of male strength and minor significance, or naturalization of violence committed by women. Hines, Brown and Dunning (2007) investigated cases of men who reported violence committed by the partner to a call center service in the United States. Among the reports, subjects reported suffering physical assaults, such as slaps, kicks and scratches, and threats of physical violence by their partners. About $50 \%$ of respondents reported fearing retaliation if the partners discovered the complaint.

A study conducted by Lövestad and Krantz (2012), who investigated a sample of 424 Swedish men and women, pointed out that both men and women were perpetrators and victims of violence in the relationship, a result that could indicate gender symmetry in domestic violence. Among the investigations on violence in romantic relationships in adolescents and young adults, data collection conducted with participants of both sexes is more widespread, taking advantage of school and academic venues. In these populations, it is clear that some types of violence often occur bidirectionally, and the indices of women perpetrators and male victims are high (Fernández-Fuertes \& Fuertes, 2010; Leen et al., 2013; Reeves \& Orpinas, 2012).

In Brazil, Rafael and Moura (2014) investigated 640 women in Rio de Janeiro with the Revised Conflict Tactics Scales (CTS2), and identified high levels of violence suffered and perpetrated by them in their relationships. However, in Brazil, studies directed at male participants are less explored, and the existing ones are basically to investigate the reasons for the assault, being difficult to find researchers who provide an opportunity for men to mention that they are also assaulted (Oliveira \& Souza, 2006). In 2003, Diniz Lopes, Gesteira, and Alves Gomes, presented a survey of 40 men on marital violence. Part of the results shows that $80 \%$ of men reported suffering some form of violence in everyday marital life. Interestingly, these data are very similar to figures found with female participants. The authors mention that about the same proportion of men and women reported being victims of marital violence, even if men report that violence is a practice inherent to them. This male verbalization is understandable, as violence is socially accepted as a male action rather than a female one. 
Domestic violence is often silenced in the family in a significant proportion of cases (Otálvaro \& Amar, 2011). This silence is sometimes related to the naturalization of domestic violence, as the experience of violent family models learned in childhood can be carried to the romantic relationship as a usual way to resolve conflicts (Razera, Cenci \& Falcke, 2014). Barreto, Bucher-Maluschke, Almeida and DeSouza (2009) mention the importance of an extensive and historical understanding of violence, since it may be related to transgenerational transmission, inherited from a violent family relationship pattern. The union of a couple may even be motivated by the search for similarity or complementarity of known relationships that were provided by families of origin (Silva, Menezes, \& Lopez, 2010).

The impact of the different experiences of violence in the family of origin on the occurrence of domestic violence in adulthood is well established in the literature. (Marasca, Colossi, \& Falcke, 2012). Physical violence becomes a form of relationship and conflict resolution, becoming part of the history of a particular family group (Falcke \& Féres-Carneiro, 2011). Reichenhein, Dias and Moraes (2006), in a study conducted in health services in the city of Rio de Janeiro, verified that couples who use physical violence to resolve their conflicts tend to physically assault their children, which indicates that, in many cases there is a violent family background. Specifically among men, some studies identify physical and sexual abuse in childhood as strong predictors for violence perpetration in intimate relationships, as well as witnessing a violent parental relationship (Fang \& Corso, 2008; Fergusson, 2011; Padovani \& Williams, 2011).

Providing scientific attention to the issue of intimate partner violence allows for the development of clinical interventions, aiming at improving the couple's health and future relationships of family members, in order to break the cycle of violence that occurs transgenerationally. Avoiding the identification of victims and/or perpetrators, we highlight the need to understand how domestic violence is presented and the factors contributing to its occurrence in a male sample. Under these conditions, the present study aims to investigate the presence of physical violence suffered and perpetrated by men in marital relationships, also considering the predictive power of family-of-origin experiences for the occurrence of physical violence in marital relationships.

\section{Method}

This is a quantitative research with descriptive, correlational, and explanatory design.

\section{Participants}

The present study included 186 men, heterosexual, married or living together/in civil union and residents in the metropolitan area of Porto Alegre (Brazil). Age range of participants was from 22 years to 81 years $(M=41.37 ; S D=12.63)$. Table 1 describes the sample characteristics.

Regarding years at work, it varied from zero to 48 years $(M=16.89 ; S D=11.29)$, while the income

Table 1

Frequencies and percentages of the sociodemographic characteristics of the sample $(N=186)$

\begin{tabular}{lccc}
\hline \multirow{2}{*}{ Marital status } & Characteristics & $\mathrm{N}$ & $\%$ \\
\hline \multirow{2}{*}{ Previous marriage } & Officially married & 104 & 57.1 \\
& Living together & 78 & 42.9 \\
\hline \multirow{2}{*}{ Children } & Yes & 45 & 24.3 \\
& No & 140 & 75.7 \\
\hline \multirow{2}{*}{ Education } & Yes & 118 & 64.1 \\
& No & 66 & 35.9 \\
\hline \multirow{2}{*}{ Conducts remunerated activity } & Elementary School & 18 & 10.5 \\
& High School & 82 & 47.7 \\
& Higher Education (in progress or completed) & 72 & 41.9 \\
\hline
\end{tabular}


of participants ranged between zero and 45,000 Brazilian Reais monthly ( $M=4,293,47 ; S D=5,202,38)$. Respondents reported that the relationship length ranged from one to 56 years $(M=14.83, S D=11.81)$. Among participants who reported having children, the number of children ranged from one to five $(M=1.84$, $S D=0.911)$.

\section{Instruments}

For data collection, the following instruments were used:

Sociodemographic data questionnaire: composed of 19 questions in order to identify the characteristics of the participants, such as age, education, occupation, income, relationship length, children, and others.

Revised Conflict Tactics Scales (CTS2): scale developed by Straus et al. (1996) and adapted to Portuguese by Moraes, Hasselmann and Reichenheim (2002). It aims to identify violence in the marital relationship, and consists of 78 items describing the actions of the respondent (committed violence) and of his partner (suffered violence), divided into five subscales. In the present study, the subscale of physical violence was assessed. The authors define physical violence as minor (push, grab, slap, throw objects, twist arm and pull the hair) or severe (punch, hit, kick, throw against the wall, burn or scald, use a knife or firearm). In this study, the total Cronbach's alpha of the CTS2 scale was 0,872 , and for each subscale it was as follows: severe physical violence committed $(0,858)$; severe physical violence suffered $(0,769)$; minor physical violence committed $(0,772)$; minor physical violence suffered $(0,826)$.

Family Background Questionnaire (FBQ): Questionnaire developed by Melchert (1998a, 1998b) and translated into Portuguese by Falcke (2003), with the purpose of investigating family-of-origin experiences. In this study, the following subscales were used, with indication of the Cronbach's alpha obtained: physical neglect $(0,776)$, paternal $(0,861)$ and maternal $(0,797)$ physical abuse, sexual abuse $(0,290)$, psychological adjustment of fathers $(0,781)$ and mothers $(0,739)$, parental alliance $(0,862)$ and paternal $(0,937)$ and maternal $(0,880)$ substance abuse. The Cronbach's alpha of the sexual abuse subscale is low, because the questions investigate different people who may have committed abuse (father, mother, close relative, stranger, among others), and agreement is not expected in these items.

\section{Data Collection and Analysis Procedures}

The present study, part of a larger project entitled "Predictor variables of marital violence: family-of-origin experiences, and personal and relational characteristics”, was approved by the Research Ethics Committee of the University through opinion n. 11/129 and aimed at meeting the recommendations proposed by the Resolution n. 466/2012 of the National Health Council. The sample was selected by convenience, through the indication of acquaintances, composing a "snowball" sampling. The research team was trained for the administration of the instruments.

Research assistants contacted the indicated participants via phone, inviting them to participate in a study on marital relationships. Upon acceptance, the venue was arranged as indicated by them. Prior to the administration of the instruments by trained research assistants, participants signed the Informed Consent Form (ICF) in two copies, which presented the study objectives and procedures, besides ensuring confidentiality of data and the possibility of withdrawal at any anytime. The administration lasted an hour, and the instruments of this part of the research were applied in the following order: sociodemographic data, FBQ, and CTS2. It is noteworthy that between the FBQ and the CTS2 there were three other scales from the larger study.

Data were analyzed using the Statistical Package for Social Sciences (SPSS) software (version 20.0), and descriptive analyzes were performed to identify the profile of participants and the percentages of violence. In addition, the $t$ test was used for independent or paired samples, for comparison between groups, and Pearson's Correlation was used to verify the association between variables. Finally, to identify predictors of marital violence, we used regression analysis with the stepwise method. The level of significance was set at 5\%.

\section{Results}

To evaluate violence in marital life, descriptive analyses of the CTS2 were performed. The percentages of physical violence that men reported suffering or committing at some point in the relationship are displayed in Figure 1.

We observed that minor physical violence is the type of violence that occurs more often in the investigated relationships (around 25\%). Comparing the means obtained according to the frequency of severe physical violence $(t=2,345, p=0.02)$, we verified that there were significant differences indicating that men reported being victims $(\mathrm{m}=3.43$; $\mathrm{sd}=0.87)$ significantly more often than perpetrators of severe physical violence $(\mathrm{m}=2.86$; $\mathrm{sd}=0.66)$. 
Experiences in the families of origin were measured by the FBQ, which pointed out participants' exposure to violence as direct victims or witnesses of interparental violence. Many correlations, although of low magnitude, were observed between the experiences in their family of origin and the present domestic violence, as displayed in Table 2.

We found that physical or sexual abuse, neglect, and psychological adjustment of parents were associated with physical marital violence. On the other hand, substance abuse by parents and parental alliance did not relate. To assess issues related to predictors of marital violence we performed regression analysis, using the stepwise method. Results showed that paternal physical abuse $\left(\mathrm{R}^{2}=0.106\right)$ appeared as a predictor of physical violence committed by men in their marital relationship, as displayed in Table 3. For this analysis, the dimension of global physical violence

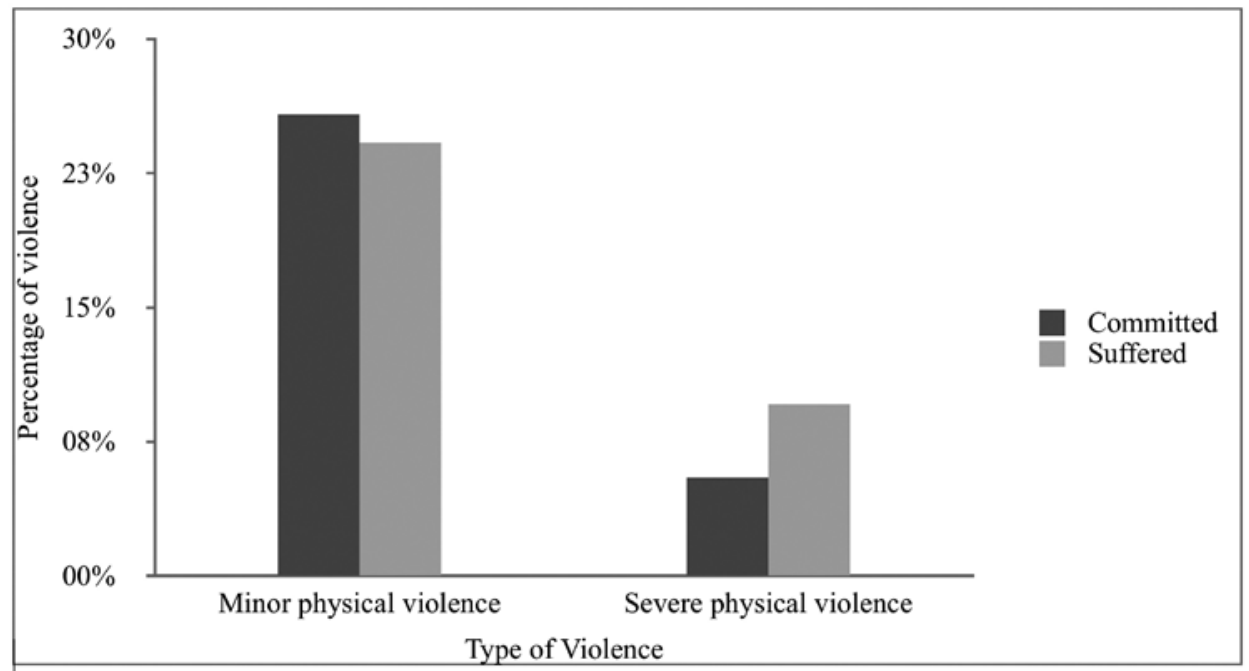

Figure 1. Percentage of occurrence of marital violence committed and suffered by men

Table 2

Correlations between dimensions of the FBQ and violence of the CTS2

\begin{tabular}{lccccc}
\hline & \multicolumn{2}{c}{$\begin{array}{c}\text { Dimensions of Committed } \\
\text { Violence (CTS2) }\end{array}$} & & \multicolumn{2}{c}{$\begin{array}{c}\text { Dimensions of } \\
\text { Suffered Violence (CTS2) }\end{array}$} \\
\cline { 2 - 3 } \cline { 5 - 6 } Dimensions of the FBQ & $\begin{array}{c}\text { Severe physical } \\
\text { violence }\end{array}$ & $\begin{array}{c}\text { Minor physical } \\
\text { violence }\end{array}$ & & $\begin{array}{c}\text { Severe } \\
\text { physical violence }\end{array}$ & $\begin{array}{c}\text { Minor physical } \\
\text { violence }\end{array}$ \\
\hline Paternal physical abuse & $.209^{* *}$ & $.152^{*}$ & & $.155^{*}$ & $.199^{*}$ \\
Maternal physical abuse & $.152^{*}$ & .111 & & .136 & .111 \\
Sexual abuse & $.178^{*}$ & .087 & & $.220^{* *}$ & $.226^{* *}$ \\
Physical neglect & $.225^{* *}$ & .113 & & .093 & .044 \\
Paternal substance abuse & .122 & .027 & & .060 & .042 \\
Maternal substance abuse & .028 & .023 & & .031 & .059 \\
Paternal psychological adjustment & $-.288^{* *}$ & $-.271^{* *}$ & & $-.273^{* *}$ & $-.273^{* *}$ \\
Maternal psychological adjustment & $-.170^{*}$ & -.133 & & -.144 & -.099 \\
Parental alliance & -.097 & .009 & & -.128 & .034 \\
\hline
\end{tabular}

** The correlation is significant at 0.01

* The correlation is significant at 0.05 
was calculated, based on the sum of the major and minor dimensions.

We also sought to investigate the possible predictors of marital violence suffered by men. It was observed that paternal physical abuse $\left(\mathrm{R}^{2}=0.087\right)$ appears again as the predictor variable of overall physical violence (severe and minor) suffered by men in their intimate relationships.

\section{Discussion}

The results indicate the presence of physical violence in intimate relationships of part of the sample (around 25\%, considering the dimension of minor physical violence), both for committing and for suffering physical assaults. We should also consider the possibility of underreporting, as participants can minimize their acts of violence for knowing that these are condemnable acts (Falcke, Boeckel, Arpini, \& Madalena, 2015). In this study, the use of a sample composed of men in the general population, revealed greater symmetry in their perception of physical violence in the marital relationship. Studies conducted in different countries have already yielded results that indicate that domestic violence does not occur exclusively by men victimizing the partner (Carmo, Grams \& Magalhães, 2011; Drijber, Reijnders \& Ceelen, 2013; Hines, Brown \& Dunning, 2007; Whitaker, Haileyesus, Swahn \& Saltzman, 2007). This finding reinforces the hypothesis of greater gender symmetry, which has been recognized in the academy by the studies on marital violence, especially in investigations with non-clinical populations (Straus, 2010).

Machado and Matos (2014) emphasize that the issue of male victimization in intimate relationships is still quite controversial and neglected; however, literature has provided space for these issues to be explored and discussed. As mentioned by Rafael and Moura (2014), a gender-exclusive perspective on the complex phenomenon of domestic violence can be immobilizing. Without any pretension to reinforce the old female role of responsible for household conflicts, the goal is the possibility of looking at these abusive relationships, suggesting that their origins and consequences can be shared, expanding the focus of study and intervention, and considering the suffering of all involved (Rafael \& Moura, 2014). Given that the establishment of violent marital relationships in adulthood appears to be strongly linked to experiences in the families of origin, the investigation of these aspects in the present study corroborates the literature (Marasca, Colossi \& Falcke, 2012; Vieira, Perdona \& Santos, 2011), highlighting the impact of violence experiences in the past, especially with the father figure. The dimensions paternal physical abuse, which addresses physical violence inflicted by the father against the subject in childhood and adolescence, and paternal psychological adjustment, which includes issues on violence committed by the father against the mother, proved to be correlated to different expressions of physical assault in participants' marital relationships. However, maternal physical abuse and maternal psychological adjustment also proved to be associated to severe physical violence committed by them.

Table 3

Experiences in the family of origin committed and suffered by men

\begin{tabular}{|c|c|c|c|c|c|c|}
\hline \multirow{4}{*}{$\begin{array}{l}\text { Experiences in the } \\
\text { family of origin } \\
\text { and violence } \\
\text { committed by men }\end{array}$} & \multicolumn{3}{|c|}{ Non-standardized coefficients } & \multicolumn{3}{|c|}{$\begin{array}{l}\text { Standardized } \\
\text { Coefficients }\end{array}$} \\
\hline & Model variables & B & $\begin{array}{c}\text { Standard } \\
\text { Model }\end{array}$ & Beta & $\mathrm{T}$ & Sig \\
\hline & Paternal physical abuse & -.209 & .070 & -.325 & -2.994 & 0.004 \\
\hline & $\mathrm{R}=0.325^{\mathrm{b}}$ & $R^{2}=0.106$ & $R^{2}$ adjusted $=0.094$ & & & \\
\hline \multirow{4}{*}{$\begin{array}{l}\text { Experiences in the } \\
\text { family of origin } \\
\text { and violence } \\
\text { suffered by men }\end{array}$} & & \multicolumn{2}{|c|}{ Non-standardized coefficients } & & \multicolumn{2}{|c|}{$\begin{array}{l}\text { Standardized } \\
\text { Coefficients }\end{array}$} \\
\hline & Model variables & B & $\begin{array}{c}\text { Standard } \\
\text { Model }\end{array}$ & Beta & $\mathrm{T}$ & Sig \\
\hline & Paternal Physical Abuse & -.245 & .093 & -.295 & -2.642 & 0.010 \\
\hline & $\mathrm{R}=0.295^{\mathrm{b}}$ & $R^{2}=0.087$ & $R^{2}$ adjusted $=0.075$ & & & \\
\hline
\end{tabular}


Padovani and Williams (2011), investigated parenting styles of origin in men with and without a history of marital violence, and identified greater presence of past experiences of violence among perpetrators, being the father the main aggressor among men who used violence against their partner, and the mother among those who did not. When comparing the type of physical assault practiced by father and mother, it was observed that the father perpetrated the most severe assaults. Similarly, Vieira, Perdona and Santos (2011) report that women who witnessed their mothers being assaulted have higher chances of suffering physical violence, but these rates are even higher with men who saw their mothers being assaulted by fathers. Such data may indicate that the violence suffered and committed by each parent brings a distinct impact on how aggression can manifest in their children's future intimate relationships.

Regression analyses showed paternal physical abuse as a predictor of physical violence against and committed by men in intimate relationships. In addition to the roles taken by father and mother in the occurrence of domestic violence, Fergusson (2011) indicates that, unlike women, who are more sensitive to the witnessing of interparental violence, for men the most important risk factor for the outbreak of violence between partners in adult life was the experience of childhood physical abuse. The conclusion was similar to that found by Alexander (2011), who identifies physical abuse committed by the father as a great predictor of perpetration of spousal assault, as well as the experience of child sexual abuse.

The phenomenon of domestic violence is complex and reveals a number of factors that influence its occurrence. The literature strongly emphasizes the impact of the baggage brought by the spouses from their families of origin, which end up favoring violence. This "violent family language," which is perpetuated through generations, interferes on the way of establishing relationships and on the repertoire of strategies for conflict resolutions, causing violence to remain naturalized in the family. Therefore, it is important to refer how it can be physically and psychologically harmful to be exposed to a violent relationship, be it family and/or marital. Furthermore, the identification of such relationship patterns can contribute to breaking the cycle and the perpetuation of violence.

Throughout our analyses, the fragility of the network to care for women in situations of violence and the almost nonexistent network for men were noteworthy, which may be a reflection of current policies (Oliveira \& Souza, 2006). In this sense, interventions with the couples and their children are important as a means of preventing future situations of violence or the increase of existing violence.

\section{Final Considerations}

This study aimed to investigate the presence of physical violence perpetrated and suffered by men in marital relationships, also considering violence experiences in their families of origin. Given the social conditions and the importance of the feminist movement in denouncing these situations, there is a tradition in which women exposed to violence in their marital relationships are often the focus of attention, therefore the literature directed to men in the context of domestic violence is still little explored and deserves further scientific attention. We did not aim at naming victims and perpetrators, but at understanding how the phenomenon presents itself and the factors that contribute to its occurrence in a male sample, a standpoint that is still little explored.

One of the main differences in this study, but which may also be a limitation is the fact that participants constitute a non-clinical sample, which demonstrates that the findings could be different and greater if we used another type of sample. The data show that an alarming percentage of people suffered or perpetrated some kind of violence in their marital and/or family relationships throughout life. It should be noted that violence is often naturalized and unidentified, and tends to be adopted as a usual way of conflict resolution. If there were a different setting, it is believed that the numbers would be even greater.

This behavior, which in most cases arises from an internalized family legacy, has strong predictive power for an also violent marital relationship in adulthood because there is a tendency to repeat the patterns of relationships experienced in childhood. There is no intention to generalize the perpetuation of family violence, but this study reinforces the need for social and psychological support to children victims of family violence, in order to break or reduce the cycle of violence by learning more functional methods for conflict resolution.

This study may contribute to further research that considers the complexity of the phenomenon and the many variables associated to it, and assist in the 
instrumentalization of health professionals who deal with cases of domestic violence, since its occurrence against men is still little explored. It is also necessary to work against the naturalization and perpetuation of violence, which has brought serious physical and psychological harm to many people.

\section{References}

Alexander, P. (2011). Childhood Maltreatment, Intimate Partner Violence, Work Interference and Women's Employment, Journal of Family Violence, 26(4), 255261. doi: $10.1037 / \mathrm{a} 0015254$

Alvim, S., \& Souza, L. (2005). Violência conjugal em uma perspectiva relacional: homens e mulheres agredidos/agressores. Psicologia: Teoria e Prática, 7(2), 171-206. Recuperado em http://editorarevistas.mackenzie.br/index.php/ptp/article/ viewFile/1041/759

Barreto, A., Bucher-Maluschke, J., Almeida, P. C., \& DeSouza, E. (2009). Desenvolvimento humano e violência de gênero: uma integração bioecológica. Psicologia: Reflexão e Crítica, 22(1), 86-92. doi: 10.1590/S0102-79722009000100012

Carmo, R., Grams, A., \& Magalhães, T. (2011). Men as victims of intimate partner violence. Journal of Forensic and Legal Medicine, 18(8), 355-359. doi: 10.1016/j.jflm.2011.07.006

Cortez, M., \& Souza, L. (2008). Mulheres (in) subordinadas: o empoderamento feminino e suas repercussões nas ocorrências de violência conjugal. Psicologia: Teoria e Pesquisa, 24(2), 171-180. doi: 10.1590/S0102-37722008000200006

Diniz, N., Lopes, R., Gesteira, S., Alves, S., \& Gomes, N. (2003). Violência conjugal: vivências expressas em discursos masculinos. Revista Escola Enfermagem USP, 37(2), 81-88. doi: 10.1590/ S0080-62342003000200010

Drijber, B., Reijnders, U., \& Ceelen, M. (2013). Male victims of domestic violence. Journal of Family Violence, 28(2), 173-178. doi: 10.1007/s10896-012-9482-9

Falcke, D. (2003). Aguas passadas não movem moinhos? As experiências da familia de origem como preditoras da qualidade do relacionamento conjugal (Tese de Doutorado). Pontifícia Universidade Católica do Rio Grande do Sul, Porto Alegre, RS.
Falcke, D., \& Féres-Carneiro, T. (2011). Reflexões sobre a violencia conjugal: diferentes contextos, múltiplas expressões. Em Wagner, A. (Ed), Desafios psicossociais da familia contemporânea: pesquisas e reflexões (pp. 72-90). Porto Alegre, RS: Artmed.

Falcke, D., Boeckel, M., Arpini, M. D, \& Madalena, M. (2015). Violência conjugal: em briga de marido e mulher não se mete a colher?. Em Wagner, A., Mosmann, C., \& Falcke, D. (Eds). Viver a dois: oportunidades e desafios da conjugalidade. (pp. 79-99). São Leopoldo: Sinodal.

Fang, X., \& Corso, P. S. (2008). Gender Differences in the Connections Between Violence Experienced as a Child and Perpetration of Intimate Partner Violence in Young Adulthood. Journal of Family Violence, 23(5), 303-313. doi: 10.1007/ s10896-008-9152-0

Fergusson, C. (2011). Love is a battlefield: risk factors and gender disparities for domestic violence among Mexican Americans. Journal of Aggression, Maltreatment \& Trauma, 20(2), 227-236. doi: 10.1016/j.chiabu.2005.10.006

Fernández-Fuertes, A., \& Fuertes, A. (2010). Physical and psychological aggression in dating relationships of Spanish adolescents: motives and consequences. Child Abuse \& Neglect, 34(3), 183191. doi:10.1016/j.chiabu.2010.01.002

Harris, K. L., Palazzolo, K. E., \& Savage, M, W. (2012). 'I'm not sexist, but...': How ideological dilemmas reinforce sexism in talk about intimate partner violence. Discourse \& Societ, 23(6) 643- 656. doi: $10.1177 / 0957926512455382$

Hines, D.A., Brown, J., \& Dunning, E. (2007). Characteristics of callers to the domestic abuse helpline for men. Journal of Family Violence, 22(2), 63-72. doi: 10.1007/s10896-007-9091-1

Jong, L., Sadala, M., \& Tanaka, A. C. D. (2008). Desistindo da denúncia ao agressor: relato de mulheres vítimas de violência doméstica. Revista Escola de Enfermagem USP, 42(4), 744-751. doi: 10.1590/ S0080-62342008000400018

Leen, E., Sorbring, E., Mawer, M., Holdsworth, E., Helsing, B., \& Bowen, E. (2013). Prevalence, dynamic risk factors and the efficacy of primary interventions for adolescent dating violence: an international review. Agression and violent behavior, 18(1), 159-174. doi: 10.1016/j.avb.2012.11.015 
Lovestad, S., \& Krantz, G. (2012). Men's and women's exposure and perpetration of partner violence: an epidemiological study from Sweden. BMC Public Health, 12(1) 1-10. doi:10.1186/1471-2458-12-945

Machado, A., \& Matos, M. (2014). Homens vítimas na intimidade: análise metodológica dos estudos de prevalência. Psicologia \& Sociedade, 26(3), 726-736. doi: 10.1590/S0102-71822014000300021

Marasca, A., Colossi, P., \& Falcke, D. (2012). Violência conjugal e família de origem: uma revisão sistemática de 2006 a 2011. Temas em Psicologia, 21(1), 221-243. doi: 10.9788/TP2013.1-16

Melchert, T. P. (1998a). A review of instruments for assessing family history. Clinical Psychology Review, 18, 163-187. doi: 10.1016/S0272-7358(97)00058-5

Melchert, T. P. (1998b). Testing the validity of an instrument for assessing family of origin history. Journal of Clinical Psychology, 54, 863-876. doi: 10.1002/ (SICI)1097-4679(199811)54:7<863::AIDJCLP1>3.0.CO;2-G

Mills, T., Avegno, J., \& Haydel, M. (2006). Male victims of partner violence: Prevalence and accuracy of screening tools. The Journal of Emergency Medicine, 31(4), 447-452. doi: 10.1016/j.amepre.2009.01.024

Moraes, C., Hasselmann, M., \& Reichenheim, M. (2002). Adaptação transcultural para o português do instrumento "Revised Conflict Tactics Scales (CTS2)" utilizado para identificar violência entre casais. Cadernos de Saúde Pública, 18(1), 163-176. doi: 10.1590/S0102-311X2002000100017

Narvaz, M. G., \& Koller, S. H. (2006). Metodologias feministas e estudos de gênero: articulando pesquisa, clínica e política. Psicologia em Estudo, 11(3), 647-654. doi: 10.1590/S1413-73722006000300021

Oliveira, D.C., \& Souza, L. (2006). Gênero e violência conjugal concepções de psicólogos. Estudos e Pesquisas em Psicologia, 6(2), 34-50. Recuperado em http://pepsic.bvsalud.org/scielo.php?script $=$ sci_ arttext\&pid=S1808-42812006000200004\&lng=pt \&tlng $=$ pt.

Otálvaro, L., \& Amar, J. (2011). Violencia en la pareja, las caras del fenómeno. Salud Uninorte, 27(1), 108-123. Recuperado em http://www. scielo.org.co/scielo.php?script $=$ sci_arttext\&pid $=$ S0120-55522011000100011
Padovani, R., \& Williams, L. (2011). Estilo parental de origem e ansiedade em homens com histórico de agressão à parceira. Estudos de Psicologia, 16(3), 263 269. doi: 10.1590/S1413-294X2011000300008

Pazo, C., \& Aguiar, A. (2012). Sentidos da violência conjugal: análise do banco de dados de um serviço telefônico anônimo. Revista de Saúde Coletiva, 22(1), 253-273. doi: 10.1590/S0103-73312012000100014

Próspero, M. (2007). Mental Health Symptoms Among Male Victims of Partner Violence. American Journal of Men's Health, 1(4), 269-277. doi: 10.1177/1557988306297794

Rafael, R., \& Moura, A. (2014). Violência contra a mulher ou mulheres em situação de violência? Uma análise sobre a prevalência do fenômeno. Jornal Brasileiro de Psiquiatria, 63(2), 149-153. doi: 10.1590/0047-2085000000019

Razera, J., Cenci, C. M. B., \& Falcke, D. (2014). Violência doméstica e transgeracionalidade: um estudo de caso. Revista de Psicologia da IMED, 6(1), 47-51. doi: 10.18256/2175-5027/psico-imed.v6n1p47-51

Reeves, P., \& Orpinas, P. (2012). Dating norms and dating violence among ninth graders in Northeast Georgia: reports from student surveys and focus groups. Journal of Interpersonal Violence, 27(9), 1677 1698. doi: $10.1177 / 0886260511430386$

Reichnhein, M., Dias, A., \& Moraes, C. (2006). Co-ocorrência de violência física conjugal e contra filhos em serviços de saúde. Revista de Saúde Pública, 40(4), 595-603. doi: 10.1590/S0034-89102006000500007

Ribeiro, M. (2010). Movimento feminista na fonte dos centros de combate à violência contra mulheres. Anais do I Simpósio sobre Estudos de Gênero e Políticas Públicas, 2010. Londrina, PR, Brasil. Recuperado em http://www.uel.br/eventos/gpp/pages/arquivos/5.MonicaDias.pdf

Santos, C., \& Izumino, W. (2005). Violência contra as mulheres e violência de gênero: notas sobre estudos feministas no Brasil. Estudios Interdisciplinarios de América Latina y El Caribe, 16(1). Recuperado em http://www.nevusp.org/downloads/down083. pdf

Silva, I., Menezes, C., \& Lopes, R. (2010). Em busca da "cara-metade": motivações para a escolha do cônjuge. Estudos de Psicologia, 27(3), 383-391. doi: 10.1590/S0103-166X2010000300010 
Straus, M. (2008). Dominance and symmetry in partner violence by male and female university in 32 nations. Children and Youth Services Review, 30, 252-275. doi: 10.1016/j.childyouth.2007.10.004

Straus, M. (2011). Gender symmetry and mutuality in perpetration of clinical-level partner violence: empirical evidence and implications for prevention and treatment, Aggression and Violent Behavior, 16, 279-288. doi: 10.1016/j.avb.2011.04.010

Straus, M. (2010). Thirty years of denying the evidence on gender symmetry in partner violence: implications for prevention and treatment, Partner Abuse, 1(3), 332-363. doi: 10.1891/1946-6560.1.3.332

Straus, M. (1990). The national family violence surveys. In: Straus MA and Gelles RJ (eds) Physical Violence in American Families: Risk Factors and Adaptations to Violence in 8145 Families. New Brunswick, NJ: Transaction Publishers, pp. 3-16.
Straus, M., Hamby, S., Boney-McCoy, S. \& Sugarman, D. (1996). The Revised Conflict Tactics Scales (CTS2): Development and preliminary psychometric data. Journal of Family Issues, 17, 283-316. doi: 10.1177/019251396017003001

Vieira, E., Perdona, G., \& Santos, M. (2011). Fatores associados à violência física por parceiro íntimo em usuárias de serviços de saúde. Revista de Saúde Pública, 45(4), 730-737.doi: 10.1590/ S0034-89102011005000034

Whitaker, D. J., Haileyesus, T., Dwahn, M., \& Saltzman, L. (2007). Differences in frequency of violence and reported injury between relationships with reciprocal and nonreciprocal intimate partner violence. American Journal of Public Health, 97(5), 941-947. doi: 10.2105/AJPH.2005.079020

Recebido em 20/08/2015 $1^{\text {a }}$ reformulação: 02/12/2015 $2^{a}$ reformulação: 31/01/2016 Aceito em: 01/02/2016

Sobre os autores:

Aline Riboli Marasca é Psicóloga pela Universidade do Vale do Rio dos Sinos (UNISINOS), Especialista em Psicodiagnóstico e Avaliação Psicológica pelo Instituto Contemporâneo (CIPT).

E-mail: aline.marasca@gmail.com

Josiane Razera é Psicóloga pela Faculdade Meridional (IMED). Doutoranda e Mestre em Psicologia Clínica pela Universidade do Vale dos Sinos (UNISINOS). Especialista em Dinâmicas das Relações Conjugais e Familiares pela Faculdade Meridional (IMED).

E-mail: josianerazera@yahoo.com.br

Henrique Juliano Rosa Pereira é Aluno do Curso de Psicologia da Universidade do Vale do Rio dos Sinos (UNISINOS) e bolsista de iniciação científica (FAPERGS).

E-mail: henrique-juliano@hotmail.com

Denise Falcke é Psicóloga e Doutora pela Pontifícia Universidade Católica do Rio Grande do Sul (PUCRS), Coordenadora e Professora do Programa de Pós-Graduação em Psicologia Clínica da Universidade do Vale do Rio dos Sinos (UNISINOS).

E-mail:dfalcke@unisinos.br

\section{Contato com os autores:}

Universidade do Vale do Rio dos Sinos, Centro de Ciências da Saúde

Av. Unisinos, 950 - Sala 2A109 - Bairro Cristo Rei

São Leopoldo-RS, Brasil

CEP: 93022-000 